\title{
ALIDISSI, a Research Program to Evaluate Electrochemical Impedance Spectroscopy as a SoC and SoH Diagnosis Tool for Li-ion Batteries
}

\author{
V. Sauvant-Moynot ', J. Bernard' ', R. Mingant ${ }^{1}$, A. Delaille'2, F. Mattera' ${ }^{2}$, S. Mailley ${ }^{3}$, \\ J.-L. Hognon ${ }^{4}$ and F. Huet ${ }^{5}$ \\ 1 Institut français du pétrole, IFP-Lyon, Rond-point de l'échangeur de Solaize, BP 3, 69360 Solaize - France \\ 2 CEA-LITEN, INES, Savoie Technolac, 50 avenue du Lac Léman, BP 332, 73337 Le Bourget-du-Lac Cedex - France \\ 3 CEA-LITEN, 17 rue des Martyrs, 38054 Grenoble Cedex 9 - France \\ 4 Material Mates, Guilletière, 39700 Sarcenas - France \\ 5 CNRS UPR 15-LISE, UPMC-Paris 6, Université Pierre et Marie Curie, 4 place Jussieu, 75252 Paris Cedex 05 - France \\ e-mail: valerie.sauvant@ifp.fr - julien.bernard@ifp.fr - remy.mingant@ifp.fr - arnaud.delaille@cea.fr - florence.mattera@cea.fr \\ sophie.mailley@cea.fr - jean-luc.hognon@wanadoo.fr - francois.huet@upmc.fr
}

Résumé - ALIDISSI, un programme de recherche destiné à évaluer la spectroscopie d'impédance électrochimique comme outil de détermination de l'état de charge et de l'état de santé des batteries lithium-ion - ALIDISSI est un projet de recherche français dont l'objectif est d'évaluer l'utilité de la Spectroscopie d'Impédance Électrochimique (SIE) comme outil de diagnostic pour les batteries Li-ion. Cet outil pourra être utilisé pour le diagnostic des batteries de véhicules hybrides et des systèmes de stockage de l'énergie d'origine photovoltaïque. Cet article a pour objectif de présenter le projet ALIDISSI. Il décrit la méthodologie mise en place et les procédures originales définies pour accélérer le vieillissement d'éléments de batteries Li-ion. Les profils de vieillissement ont été définis pour être représentatifs de l'application et font suite à une étude bibliographique des mécanismes de vieillissement et des facteurs influençant le vieillissement. Les premiers résultats d'impédance obtenus à partir d'un couple d'électrodes conventionnel $\left(\mathrm{LiNiCoAlO} /\right.$ graphite) et d'un couple émergent $\left(\mathrm{LiFePO}{ }_{4} / \mathrm{Li}_{4} \mathrm{Ti}_{5} \mathrm{O}_{12}\right)$ sont présentés ici. Ils ont été obtenus sur des éléments prototypes ensachés de petite capacité incluant une électrode de référence.

\footnotetext{
Abstract - ALIDISSI, a Research Program to Evaluate Electrochemical Impedance Spectroscopy as a SoC and SoH Diagnosis Tool for Li-ion Batteries - ALIDISSI is a French research project aiming at evaluating Electrochemical Impedance Spectroscopy (EIS) as a diagnosis tool for Li-ion batteries to be used in future Hybrid Electric Vehicles (HEV) and on-grid photovoltaic (PV) systems. This paper describes the project methodology. A review of ageing mechanisms in lithium-ion batteries is proposed first to point out the main processes reported in the literature and their related accelerating factors. The accelerating ageing profiles developed in this project to accelerate ageing in lithium-ion batteries are described next for both applications. Preliminary results obtained on 3-electrode prototype pouch cells made with traditional electrode couple like $\mathrm{LiNiCoAlO}_{2} / \mathrm{LiC}_{6}$ and a promising electrode couple $\left(\mathrm{LiFePO} / / \mathrm{Li}_{4} \mathrm{Ti}_{5} \mathrm{O}_{12}\right)$ are also presented in the last part of this work.
} 


\section{INTRODUCTION}

The development of improved State-of-Charge (SoC) and State-of-Health $(\mathrm{SoH})$ determination methods is a current research topic for battery-powered applications. As an example, Hybrid Electric Vehicles (HEV) are in rapid extension and create a strong demand for an accurate and reliable $\mathrm{SoC}$ indicator in use. In the same way, grid-connected photovoltaic (PV) systems could take many advantages by using batteries, resulting in the same demand for a reliable $\mathrm{SoC}$ indicator. Such indicator is indeed one key parameter to further optimize the battery energy management, and constitutes thus a necessary step to increase batteries lifespan, to reduce in consequence the energy storage cost, and finally to ensure the reliability and the security of systems. So far, no one succeeded in coming up with a $\mathrm{SoC} / \mathrm{SoH}$ indicator that is reliable and precise enough under realistic user conditions.

ALIDISSI is a French research project aiming at evaluating Electrochemical Impedance Spectroscopy (EIS) as a diagnosis tool for Li-ion batteries to be used in future hybrid electric vehicles and on-grid photovoltaic systems. This paper describes the methodology and focuses on ageing tests defined to reproduce battery use in HEV and grid-connected PV applications. First results obtained on an emerging electrode couple $\left(\mathrm{LiFePO}_{4} / \mathrm{Li}_{4} \mathrm{Ti}_{5} \mathrm{O}_{12}\right)$ and on a conventional one $(\mathrm{LiNiCoAlO} /$ graphite) are presented.

\section{ALIDISSI PROJECT DESCRIPTION}

\subsection{Partnership}

The ALIDISSI project has been launched in early 2008 in the framework of the Stock-E program funded by the French "Agence Nationale de la Recherche" (ANR). The partnership includes: IFP as coordinator and CEA, two major R\&D institutes in the field of energy, the LISE which is a national research laboratory specialist on electrochemical systems, and Material Mates an equipment manufacturer for electrochemistry and materials science laboratories.

The goals of the ALIDISSI project are to improve the performances of Li-ion batteries (capacity, life cycle) and to develop the EIS as an in-situ method for battery diagnosis in HEV and on-grid PV systems.

\subsection{Electrochemical Impedance Spectroscopy}

Many attempts to use impedance parameters (complex $a c$ impedance in electrochemistry, internal resistance in electrical engineering) to determine the $\mathrm{SoC}$ and $\mathrm{SoH}$ of batteries, mainly lead-acid batteries, have been performed for the last three decades. The most promising parameters can be measured in the high-frequency domain so that EIS appears as a non-pertubative, fast, and easy-to-measure technique [1].
One of the key parameters that was found to be related to the $\mathrm{SoC}$ and/or the $\mathrm{SoH}$ in various types of batteries is the highfrequency resistance $R_{\mathrm{HF}}$ at which the imaginary part of the cell impedance is equal to zero. Another parameter is the frequency at which $R_{\mathrm{HF}}$ is measured, that is the frequency at which the cell switches from a capacitive behaviour at lower frequencies to an inductive behaviour at higher frequencies $[1,2]$. This parameter was observed to vary monotonously with the SoC of Ni-MH and Ni-Cd batteries [2] .

The application of EIS with a 3-electrode set-up to Li-ion cells in function of current, temperature and during representative charge cycles will help to determine electrochemical phenomena occurring at both electrodes [1, 3-7]. Particular attention will be paid on ageing mechanisms for emerging electrode technologies, which need to be clarified. Results obtained will contribute to a better understanding of EIS spectra measured with a 2-electrode set-up on commercial Li-ion systems, enlarging the application scope of work. On the basis of impedance parameters representative of SoC and $\mathrm{SoH}$, it is intended to develop and validate a new tool of non intrusive and in-situ diagnosis for batteries.

\subsection{Li-ion Cells}

An emerging electrode couple $\left(\mathrm{LiFePO} / \mathrm{Li}_{4} \mathrm{Ti}_{5} \mathrm{O}_{12}\right)$ and a conventional one $\left(\mathrm{LiNiCoAlO}_{2} /\right.$ graphite) will be studied. Indeed, attributes such as cell potential, energy and power densities are related to the intrinsic property of the positive and negative electrode materials. It is of interest to investigate two different $\mathrm{Li}$-ion cell technologies, including an emerging electrode couple expected to play a key role in traction batteries thanks to its electrochemical stability.

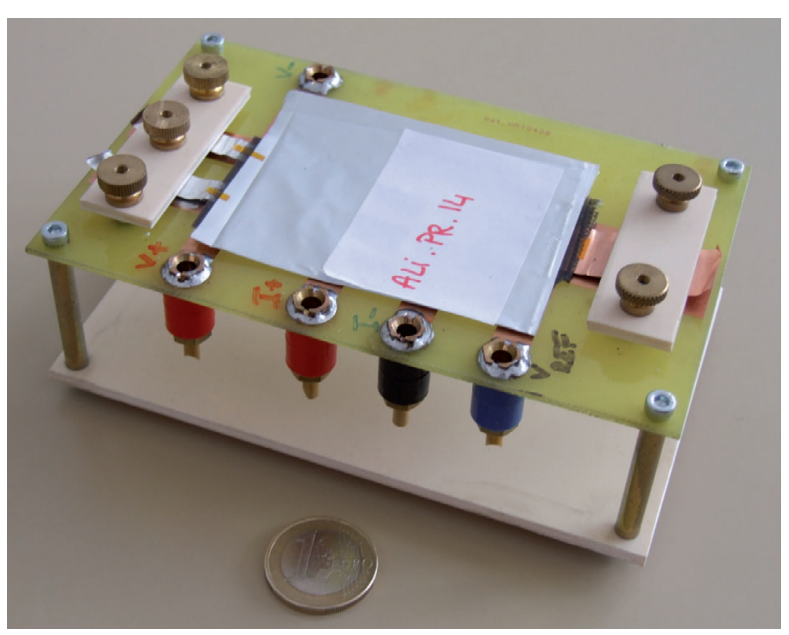

Figure 1

Pouch cell $\mathrm{LiFePO}_{4} / \mathrm{Li}_{4} \mathrm{Ti}_{5} \mathrm{O}_{12}$ on testing support. 
Pouch cells with nominal capacity around $5 \mathrm{mAh}$ were designed with positive and negative electrode surface of $2 \mathrm{~cm}^{2}$ and a Lithium reference. Conventional liquid electrolyte was injected into the electrode and separator materials before sealing. Figure 1 gives a picture of the pouch cell with $\mathrm{LiFePO} / \mathrm{Li}_{4} \mathrm{Ti}_{5} \mathrm{O}_{12}$ on the testing stand. The electrochemical test bench for the cell formation was a EIS Biologic potentiostat. Tests were performed between $1.0 \mathrm{~V}$ and $2.6 \mathrm{~V}$ in the case of the $\mathrm{LiFePO}_{4} / \mathrm{Li}_{4} \mathrm{Ti}_{5} \mathrm{O}_{12}$ and between $3.0 \mathrm{~V}$ and $4.3 \mathrm{~V}$ with $\mathrm{LiNiCoAlO}_{2} /$ graphite. Nominal capacities were measured for each cell.

\section{AGEING MECHANISMS IN LITHIUM-ION BATTERIES}

\subsection{State-of-the-Art}

A review of ageing mechanisms in lithium-ion batteries is proposed first to point out the main processes reported in the literature and their related accelerating factors. The ageing mechanisms occurring at the negative and positive electrodes differ significantly and interact with the electrolyte ageing. Additional changes may concern the composite electrodes (corrosion of the current collector, disbonding between current collector and electrodes, binder ageing, porosity obstruction, etc.), the electrode-electrolyte interfaces, and the electrolyte itself (and separator as well).

\subsubsection{Negative Electrodes}

Graphite is the most important negative material in lithiumion batteries. The main ageing effects reported for carbonaceous electrodes are: [8]

\section{Solid Electrolyte Interphase (SEI)}

SEI layers formed at the graphite electrode/electrolyte interface due to reactions of the anode with the electrolyte components are considered to be the major source of ageing. SEI formation depends on the electrolyte composition as SEI is composed of electrolyte decomposition products [8]. Occurring mainly at the beginning of cycling, this process is associated with the surface impedance rise which can be related to power fade. Even though SEI offers protection to the electrolyte components towards further reduction and to the electrode against corrosion, irreversible charge capacity loss and self-discharge reactions can be observed after prolonged cycling. Therefore, the capacity fade due to corrosion of $\mathrm{Li}_{x} \mathrm{C}_{6}$, electrolyte loss, and further SEI formation and growth related to electrolyte decomposition are ongoing throughout the battery life. It is worth noting that elevated temperatures are very detrimental to SEI stability, causing the SEI film to break down and dissolve.

\section{Lithium metal plating}

Metallic lithium plating and lithium dendrite growth are parasitic side reactions that may affect the graphite electrode during charging in the case of slow diffusion of lithium ions into carbon. Enhanced by low temperatures, interestingly, subsequent reactions of $\mathrm{Li}$ metal with the electrolyte induce further ageing and capacity fade [9] (loss of $\mathrm{Li}^{+}$charge carriers).

The spinel $\mathrm{Li}_{4} \mathrm{Ti}_{5} \mathrm{O}_{12}$ material is an alternative good candidate as negative electrode with a good reversibility, a stable operating voltage of approximately $1.5 \mathrm{~V} v s$ lithium, and no structural change (zero-strain insertion material). The exceptional stability of this electrode was demonstrated at $60^{\circ} \mathrm{C}$ and $80^{\circ} \mathrm{C}[10]$.

\subsubsection{Lithium Metal Oxide Positive Electrodes}

In general, charge capacity fading of positive active material can originate from three basic principles [8]:

\section{Structural changes during cycling}

The insertion/extraction of lithium ions leads to changes in the molar volume of the materials, inducing stress and strain to the electrode and resulting in possible micro-craking. Al and $\mathrm{Mg}$ dopands further stabilise the layered structure of lithium nickel cobalt oxides, even in the discharged state at high temperatures.

\section{Chemical decomposition/dissolution reactions}

Dissolution of $\mathrm{Li}(\mathrm{Ni}, \mathrm{Co}) \mathrm{O}_{2}$ in usual electrolytes does not seem to be a problem.

\section{Surface film modification}

Formation of surface film on nickel cobalt oxide electrodes due to electrolyte oxidation and $\mathrm{LiPF}_{6}$ decomposition has been reported when $\mathrm{LiPF}_{6}$-based electrolytes are used. This surface alteration leads to an impedance increase and may be accompanied by the evolution of gaseous species.

It is worth noting that there are few reported information on the ageing properties of the olivine $\mathrm{LiFePO}_{4}$ compound. The presence of impurities that may be produced by sintering was shown to be responsible for ageing (ferrous ions dissolve in the electrolyte) and for the decrease in specific capacity [11]. Besides, exposition and storage in ambient air result in a rapid attack of the surface layers of the particles coated with carbon, leading to delithiation of the surface layers [12].

\subsection{Accelerating Factors}

SoC, cycling conditions and temperature are obviously key factors to enhance or reduce the above-mentioned ageing mechanisms:

- high SoC promotes SEI formation at the negative electrode/electrolyte interface;

- lithiation/delithiation processes lead to potential microcracking in the positive active material;

- low SoC enhances the SEI formation at the positive electrode/electrolyte interface with $\mathrm{LiPF}_{6}$-based electrolyte; 
- high cycling rate is an accelerating factor of ageing mechanisms in general [13];

- high temperatures activate chemical reactions such as electrolyte decomposition and diffusion processes but destabilised SEI layers, leading to further SEI growth; temperature changes favour mechanical stresses and strains within electrode materials; low temperature favours Li plating and related ageing mechanisms.

\section{ACCELERATED AGEING TESTS FOR HEV APPLICATION}

\subsection{Objectives}

The purposes of a specific accelerated ageing test are:

- to highlight and discuss the ageing mechanisms of two different $\mathrm{Li}$-ion technologies (doped $\mathrm{LiNiCoAlO}_{2} /$ graphite and $\mathrm{LiFePO} / \mathrm{Li}_{4} \mathrm{Ti}_{5} \mathrm{O}_{12}$ ) within a few months test period;

- to test EIS as a non destructive method for in-situ battery diagnosis and assessment of $\mathrm{SoC}$ and $\mathrm{SoH}$ during ageing.

Given the HEV environment in terms of temperature range and dynamic cycling and the ageing accelerated factors aforementioned, it seems particularly interesting:

- to investigate a wide $\mathrm{SoC}$ range during ageing cycling;

- to define a high cycling rate;

- to use not only a high temperature in isothermal condition but also to use temperature changes from elevated to low values, alternatively.

Since the use of EIS for the continuous observation of the effects of cycling, under field-operating conditions, on the life-time of Li-ion cells and batteries is a new application, there is no existing test standard combining EIS and cycling. In addition, there is no existing standard for acceleratedageing tests. The state-of-the-art of power-batteries ageing procedures for HEV application is briefly reviewed to propose our accelerated-ageing test.

\subsection{Review of Accelerated Ageing Test Protocols}

There are basically two approaches used to accelerate ageing: on the one hand long-lasting realistic cycles (Artemis cycle for example) lead to progressive discharge of the battery which is recharged when a minimum $\mathrm{SoC}$ value is reached; on the other hand stepwise shorter cycles can be used, aiming at separating the ageing phenomena.

The second approach is preferred in most cases when the mechanisms will be analysed from the measurements. As it is also our scope, more attention was given to ageing cycles specified in former and ongoing projects on power batteries dedicated to HEV applications. Specific procedures based on stepwise cycles were developed in the USA for the FreedomCAR Program to characterize the performances of hybrid storage device [14]. Life cycle test procedures were

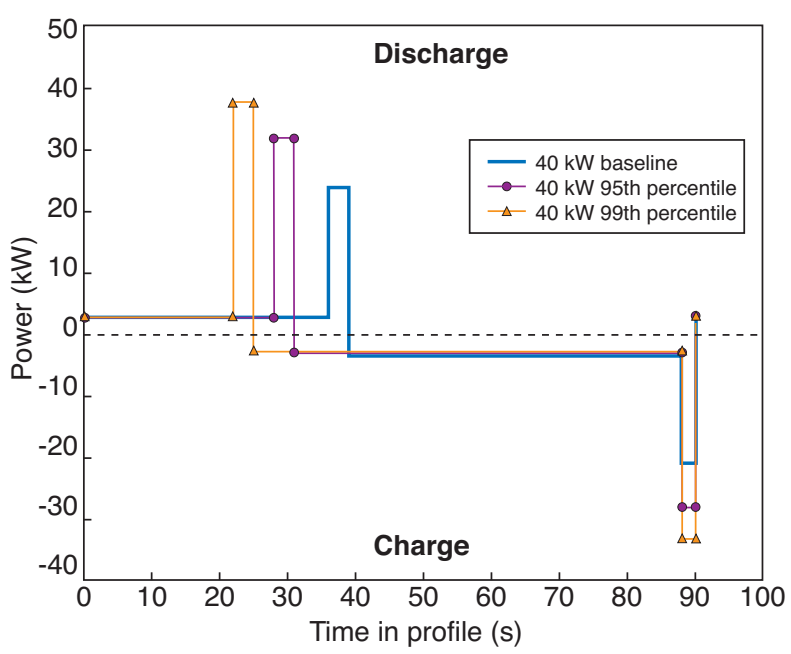

Figure 2

FreedomCAR $40 \mathrm{~kW}$ power-assist cycle life test profiles [14].

also developed in Europe for power batteries on the basis of stepwise cycles $[15,16]$.

Cycle life test profiles for power-assist batteries $(40 \mathrm{~kW})$ according to the FreedomCAR test manual are illustrated in Figure 2, as an example.

Hybrid cycle life testing is performed by repeating the test profiles at a fixed SoC (i.e. the profiles are charge-neutral). The approach specified makes use of a family of three test profiles where the baseline profile is a relatively low stress profile considered to represent an 80th percentile driving demand while two higher stress profiles are designed to represent 95th and 99th percentile load demands. A complete cycle life test regime is performed using combinations of all three profiles, with the baseline used for $80 \%$ of the total life testing, the 95th percentile used for an additional 15\%, and the 99th percentile profile used for the remaining part. For any load, test profiles are a set of 90 -second pulse profiles defined to represent four driving phases:

- start with low solicitation of the battery;

- short discharge pulse to simulate a power-assisted acceleration;

- cruise accompanied by low recharge;

- short recharge pulse to simulate regenerative braking.

According to specifications, cycle life profiles are defined in terms of power steps: the baseline profile demands $60 \%$ of the available power, the 95th percentile load demands $80 \%$ of the available power and the 99th percentile requires $95 \%$ of the available power. It is worth noting that cycle life test procedures are intended for cycling at fixed $\mathrm{SoC}$ value. So, the control of SoC required during cycling is done by slightly altering the length of one of the profile steps to force the average $\mathrm{SoC}$ to the desired value. 


\subsection{Definition of Accelerated Ageing Procedures}

\subsubsection{Cycling}

The main characteristics of cycling are the following:

- limits in voltage are defined to avoid overcharge and overdischarge of the cells;

- charged cells are 1C-discharged to the predetermined $\mathrm{SoC}_{\max }$ before the cycling starts;

- dynamic cycling are repeated over a broad SoC window (typically 80-40\%).

Micro-cycles (Fig. 3) are defined to represent driving phases such as cruise drive, acceleration and deceleration with regenerative braking; they lead to a controlled SoC decay under the hypothesis of similar faradaic efficiency in charge and discharge (Tab. 1). Cruise period duration in charge and discharge can be adjusted in function of acceptable current peak values for the studied battery.

TABLE 1

Current profile for HEV life cycle test (example given for a $5 \mathrm{C}$ rate peak current)

\begin{tabular}{c|c|c|c}
\hline $\begin{array}{c}\text { Time } \\
\text { increment (s) }\end{array}$ & $\begin{array}{c}\text { Cumulative } \\
\text { time (s) }\end{array}$ & $\begin{array}{c}\text { Current } \\
\text { (C-rates) }\end{array}$ & SoC (\%) \\
\hline 0 & 0 & 0 & 80 \\
39 & 39 & $-\mathrm{C} / 5$ & 79.78 \\
10 & 49 & $-5 \mathrm{C}$ & 78.39 \\
31 & 80 & $\mathrm{C} / 5$ & 78.57 \\
10 & 90 & $5 \mathrm{C}$ & 79.95 \\
\hline
\end{tabular}

Macro-cycles include 22 hours micro-cycling enabling to reach a predetermined $\mathrm{SoC}_{\min }$ for the studied battery followed by a $2 \mathrm{~h}$ "non cycling" period (Fig. 4).
This later is devoted to EIS measurements and rest. Then cells are charged to the predetermined $\mathrm{SoC}_{\max }$ and EIS measures are done before a new macro-cycle starts.

\subsubsection{Experimental Set-up}

The cycling profile proposed in ALIDISSI to age HEV battery storage systems is designed to allow daily EIS measurements in Open Circuit Voltage (OCV) conditions with a 3 -electrode configuration. The data base recorded will allow discussing the continuous evolution of EIS spectra for a few months ageing, in complement to full scaling of performance and EIS measurements performed every four to six weeks. The electrochemical test bench was a VMP3 multi-potentiostat from Biologic Science Instruments. Each of the channels used is equipped with EIS option allowing independent impedance measurements on each channel. Three similar cells will be aged simultaneously for reproducibility purpose. The 5-terminal measurements (with 3 potential point measurements) of modern electrochemical devices allow 3 different configurations where each cell voltage can be monitored as described in Figure 5.

\subsubsection{Charge Protocol}

The end of the partial charge of the macrocycle should be defined while allowing combined 3-electrode EIS measurements during ageing cycling. In a 3-electrode configuration the potential may be imposed between the working electrode (i.e. the positive or the negative) and the reference electrode and not between the positive and the negative, so it's impossible to perform a charge ending with an imposed potential mode. To allow daily 3-electrode EIS measurement without changing connections, it is necessary to charge the cells at a constant

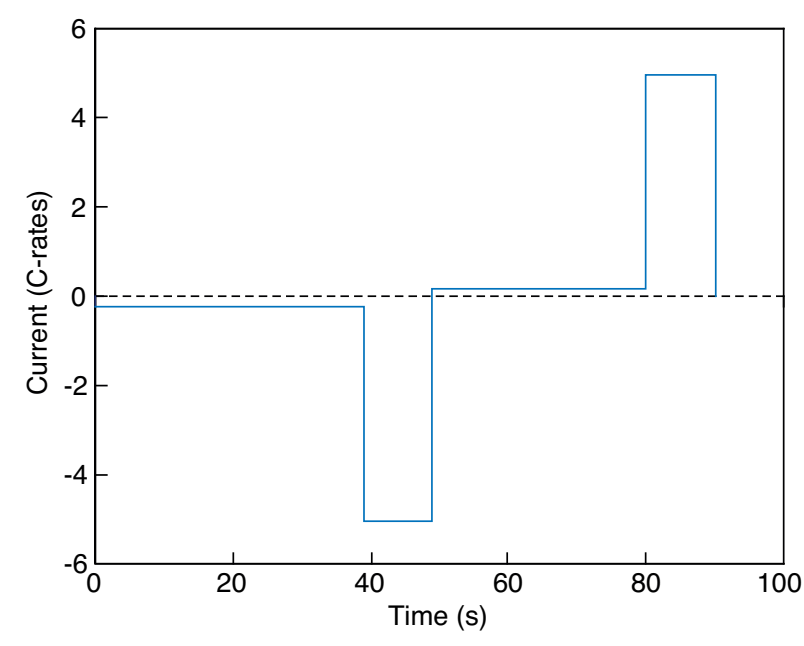

Figure 3

ALIDISSI high power battery micro-cycling profile.

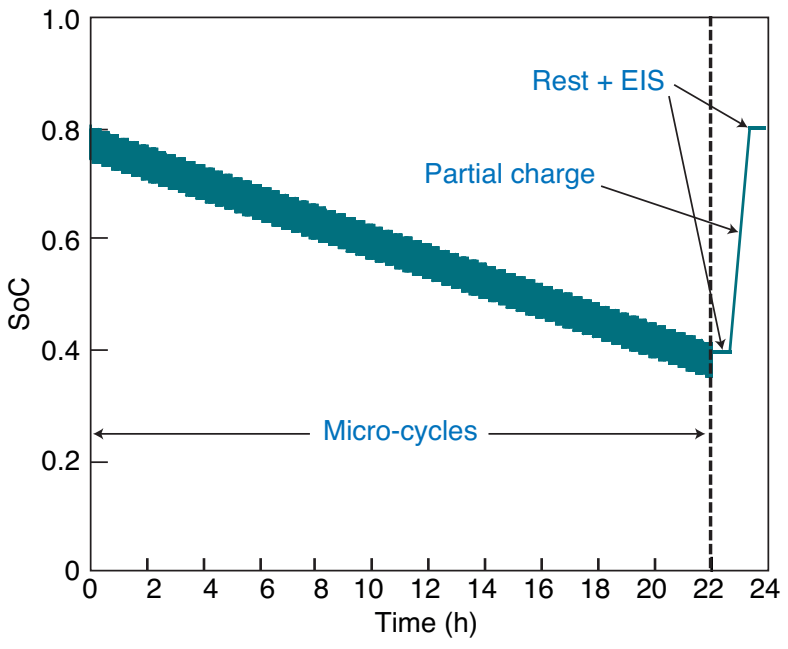

Figure 4

ALIDISSI high power battery macro-cycling profile. 
current in the partial charge protocol. In this case, the charge current must be low enough to avoid the degradation of the cell at the end of charge.

\subsubsection{Temperature}

Considering our conclusions relative to the main acceleration factors, two different ageing procedures can be proposed. Similar battery cycle profiles will be used in both cases defined with a high cycling rate over a broad $\mathrm{SoC}$ window (typically 80-40\%). Temperature conditioning will differ in both procedures to ensure normal and severe acceleration.

In order to accelerate the battery degradation mechanisms, one battery cycling $(\mathrm{C} 1)$ should be carried out at elevated temperature in almost isothermal conditions, typically around $50^{\circ} \mathrm{C}$ (depending on the battery manufacturer specifications). The other battery cycling $(\mathrm{C} 2)$, designed to be even more severe, would alternatively submit battery to elevated and low isothermal temperatures. This later arrangement will favour mechanical stresses and strains into materials to observe all possible ageing mechanisms expected to occur in a power-assist battery during HEV service.

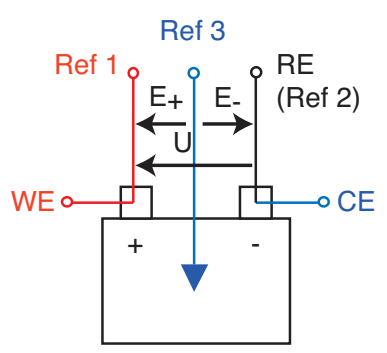

2-electrode configuration (EIS on complete cell)

$$
\begin{gathered}
U=E_{\text {Ref1 }}-E_{\text {Ref2 }} \\
E_{+}=E_{\text {Ref1 }}-E_{\text {Ref3 }} \\
E_{-}=E_{\text {Ref2 }}-E_{\text {Ref3 }}
\end{gathered}
$$

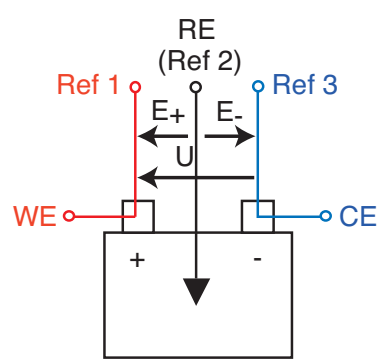

3-electrode configuration (EIS on positive electrode)

$$
\begin{gathered}
U=E_{\text {Ref1 }}-E_{\text {Ref3 }} \\
E_{+}=E_{\text {Ref1 }}-E_{\text {Ref2 }} \\
E_{-}=E_{\text {Ref3 }}-E_{\text {Ref2 }}
\end{gathered}
$$

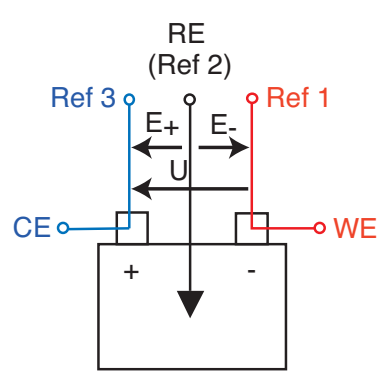

3-electrode configuration (EIS on negative electrode)

$$
\begin{gathered}
U=E_{\text {Ref3 }}-E_{\text {Ref1 }} \\
E_{+}=E_{\text {Ref3 }}-E_{\text {Ref2 }} \\
E_{-}=E_{\text {Ref1 }}-E_{\text {Ref }}
\end{gathered}
$$

Figure 5

Experimental 3-electrode set-up for EIS measurements during HEV ageing (CE for counter electrode, WE for working electrode and Ref for reference electrode)

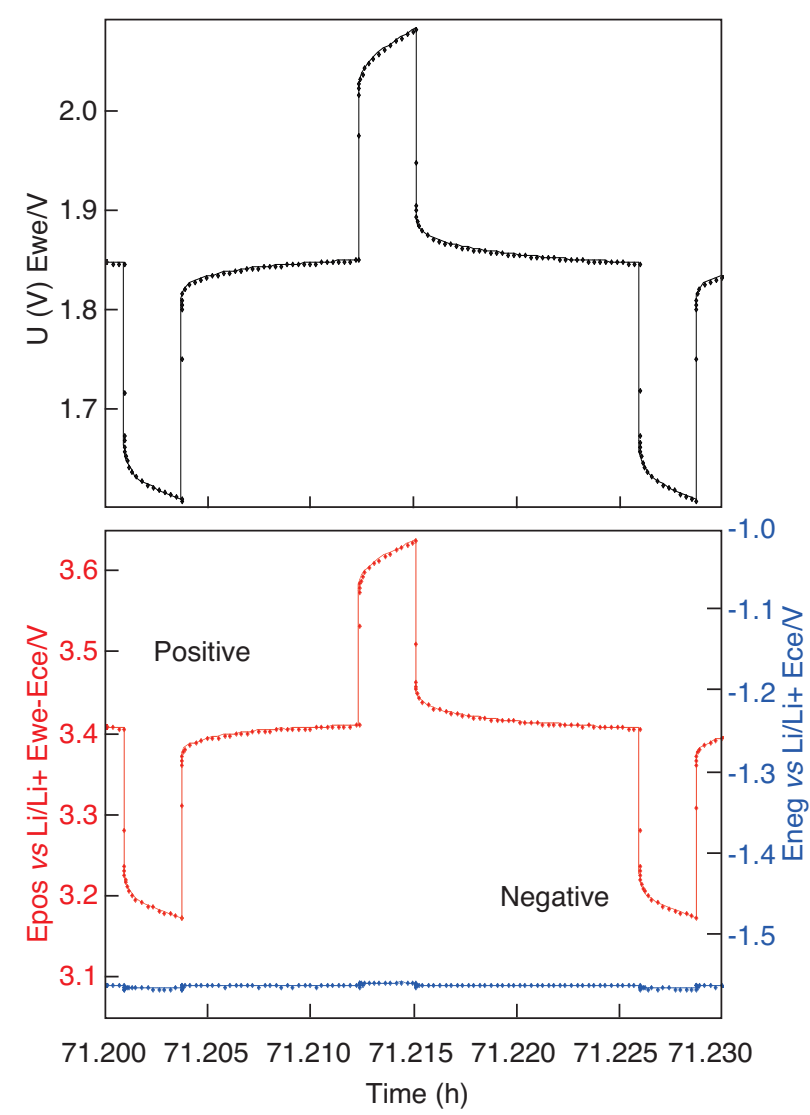

Figure 6

Typical response of a Pouch cell $\mathrm{LiFePO}_{4} / \mathrm{Li}_{4} \mathrm{Ti}_{5} \mathrm{O}_{12}$ during a microcycle. a) Voltage of the complete cell and b) individual potentials of the positive and the negative electrodes $v s$ $\mathrm{Li} / \mathrm{Li}^{+}$.

\subsubsection{Data Acquisition During Cycling}

The following parameters should be collected during cycling for each cell:

- effective current applied;

- voltage, namely potential evolution between positive and reference electrodes, potential evolution between negative and reference electrodes, potential evolution between negative and positive electrodes as shown in Figure 6 (N.B. these data are available during micro-cycling and charge/discharge protocols but are not available during EIS characterization);

- OCV after 30 min during the daily non cycling;

- EIS spectra at $\mathrm{SoC}_{\min }$ and at $\mathrm{SoC}_{\max }$ after recharge.

For further analysis, when "check-up" measurements are available (test procedure performed on each cell every four weeks during ageing), it may be useful to calculate discharged capacity, minimum voltage, charged capacity and maximum voltage for each micro-cycle but also cumulated charged and discharged capacity during the cycling day. 


\section{ACCELERATED AGEING TESTS FOR PV-GRID CONNECTED APPLICATION}

In addition to the HEV application, the purpose of the ALIDISSI project consists also in studying the possible use of Li-ion batteries in PV grid connected applications. Two additional accelerated ageing tests have thus been defined according to the expected cycling profiles of storage systems in such application.

It must be underlined here that the storage for PV applications connected to the grid is still a subject little studied in comparison with the HEV application. In consequence, no standard or ageing procedure does already exist for this kind of application. Besides, electricity storage systems can play many different roles for grid connected applications, as discussed for instance in References $[17,18]$. In order to define two accelerated ageing tests, it has been decided to only consider the two main following applications of PV systems:

\section{1 "Load levelling/peak shaving"}

Charge is stored from PV panels during the daytime and discharged during the peak demand in the evening. By the way, it can be noted here that the use of storage to level electricity costs leads to similar cycling: in that case, the charge is stored when the cost of electricity is low, and discharged when it is high. The related accelerated ageing tests are defined as indicated in Figure 7.

\section{2 "PV production levelling"}

Storage is used to smooth the intermittence - during the daytime - of the PV production which could otherwise involve critical perturbation to the grid. Given the expected cycling profiles of the storage in this application, the accelerated ageing test shown in Figure 8 has been defined.

We can finally mention that both ageing tests will be performed around $50^{\circ} \mathrm{C}$ in order to activate ageing processes.

\section{RESULTS}

\subsection{Test Procedure}

In order to study the capability of EIS measurements as a diagnosis tool for both $\mathrm{SoC}$ and $\mathrm{SoH}$ of $\mathrm{Li}$-ion cells, a test procedure called "check-up" has been defined, as indicated in Figure 9, to characterise Li-ion cells before and along ageing, typically every four weeks.

This test is divided in four consecutive cycles. The first one (identified as (1) in Fig. 9) corresponds to a residual discharge followed by a full charge, in order to ensure the battery is fully charged. The second cycle (2) corresponds to a capacity test, used to evaluate the battery $\mathrm{SoH}$ and to adapt the charge/discharge current during the two following cycles.

The SoC effect on EIS is then investigated through a series of EIS measurements during the two last cycles:

- the third cycle (3) is aimed at using EIS in potentiostatic mode after a rest time period of 30 minutes;
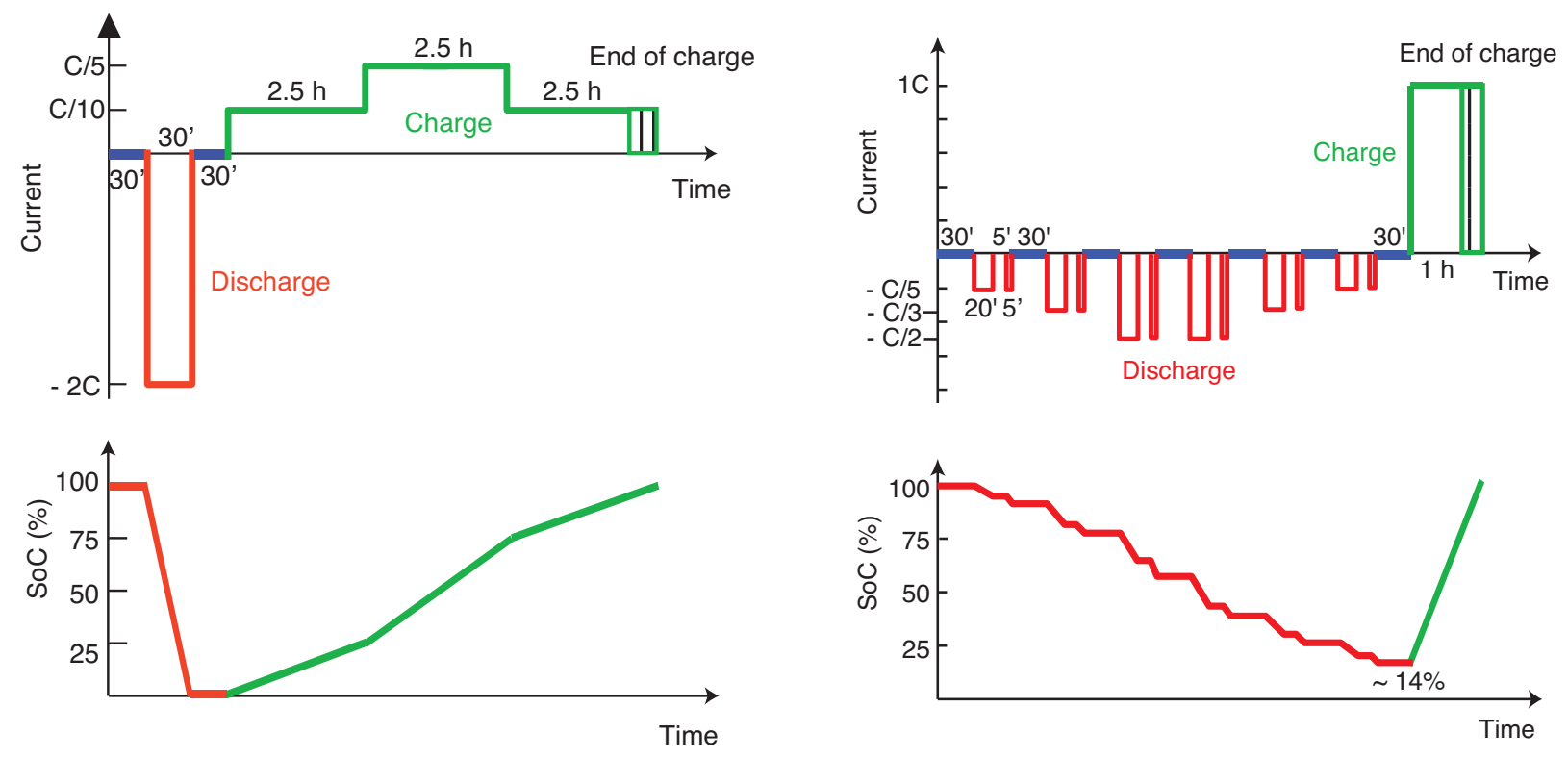

Figure 7

Accelerated ageing test according to the "peak shaving" application.

Figure 8

Accelerated ageing test according to the "PV production levelling" application. 


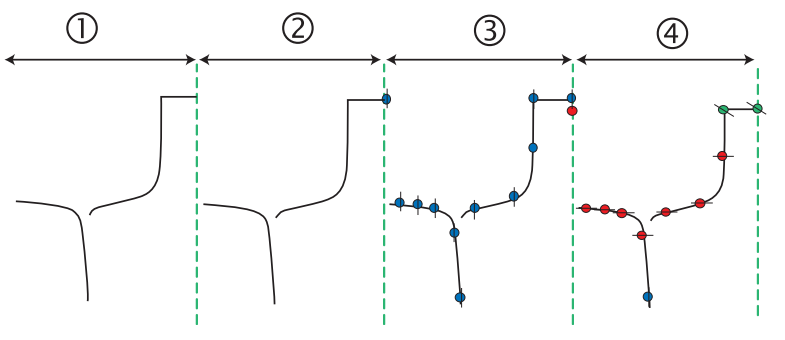

$$
\begin{aligned}
& \phi \text { EIS in potentiostatic mode after a rest time period } \\
& \text { of } 30 \text { minutes }(100 \mathrm{kHz} \text { to } 100 \mathrm{mHz}) \\
& \text { - EIS in galvanostatic mode during charge/discharge } \\
& (100 \mathrm{kHz} \text { to } 10 \mathrm{~Hz}) \\
& \text { EIS in potentiostatic mode in floating charge } \\
& \text { conditions }(100 \mathrm{kHz} \text { to } 10 \mathrm{~Hz})
\end{aligned}
$$

Figure 9

"Check-up" EIS test procedure.

- the fourth cycle (4) is aimed at using EIS during cycling without any current interruption, involving EIS measurements in galvanostatic mode during the charge/discharge, and in potentiostatic mode during the end of charge in floating mode.

Finally, SoH is investigated from the repetition of this test before and after each accelerated ageing step (see Sect. 3 and 4).

\subsection{Initial Characterization of Li-ion Cells}

The evolution of the EIS diagrams of new Li-ion cells measured in potentiostatic mode after a 30' rest time period is given in Figures 10 and 11 as a function of $\mathrm{SoC}$ for $\mathrm{LiNiCoAlO}_{2}$ /graphite and $\mathrm{LiFePO}_{4} / \mathrm{Li}_{4} \mathrm{Ti}_{5} \mathrm{O}_{12}$ cells, respectively. Impedance responses of the entire cell (2-electrode EIS) and of both positive and negative electrodes (3-electrode EIS) are presented. In all cases, the validity of the measurement was checked by comparing the sum of the half-cell impedances to the cell impedance.

The impedance of the $\mathrm{LiNiCoAlO}_{2} /$ graphite cells is composed of two partially overlapping semi-circles, which are clearly due to the positive electrode. This diagram is quite different from the 3-electrode EIS Nyquist plots reported in the literature $[4,6]$ for similar Li-ion technologies for which the contribution of the negative electrode is more substantial. However, the reproducibility and self-consistency of the measurements were checked on a panel of 10 cells, so that the pouch cells under study are considered to enable the investigation of EIS potentiality as a SoC and SoH indicator. Looking at the Nyquist plot evolution with the SoC, it appears that the high-frequency semi-circle does not evolve with the $\mathrm{SoC}$ whereas the low-frequency one shows a nonlinear evolution. The high-frequency semi-circle can be ascribed to a surface film according to the literature [19].

A better understanding of the phenomena will be achieved along ageing thanks to the EIS diagnosis and the final postmortem analysis. The low-frequency semi-circle was ascribed to the charge-transfer process of the $\mathrm{LiCoO}_{2}$ positive material, highly resistive when $\mathrm{Li}^{+}$ions are fully intercalated or deintercalated. This explains its strong dependence on the SoC already reported [4].

For the $\mathrm{LiFePO}_{4} / \mathrm{Li}_{4} \mathrm{Ti}_{5} \mathrm{O}_{12}$ cells, a single semi-circle in the medium frequency range and a straight line in the low frequency range can be observed. This line reflects the diffusion processes that can be modeled by a Warburg impedance with a $45^{\circ}$ slope. According to Figure $11 \mathrm{~b}$, the contribution of the positive electrode impedance is predominant in the cell impedance. For a SoC ranging between $0 \%$ and $80 \%$, no
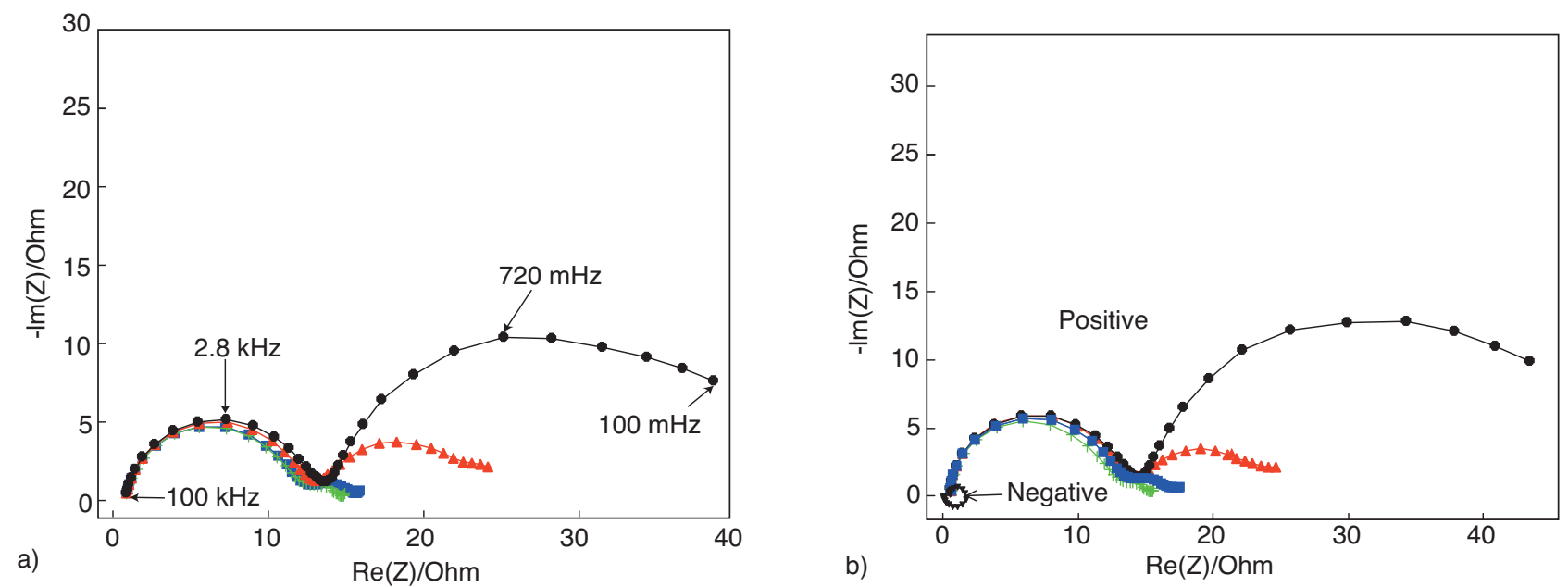

Figure 10

EIS diagrams for a Pouch cell $\mathrm{LiNiCoAlO}_{2} /$ graphite obtained during initial characterization at $20^{\circ} \mathrm{C}$. a) Entire cell; b) positive and negative electrodes. SoC 100\% (black circles), 80\% (blue squares), $40 \%$ (green crosses), and 0\% (red triangles). 

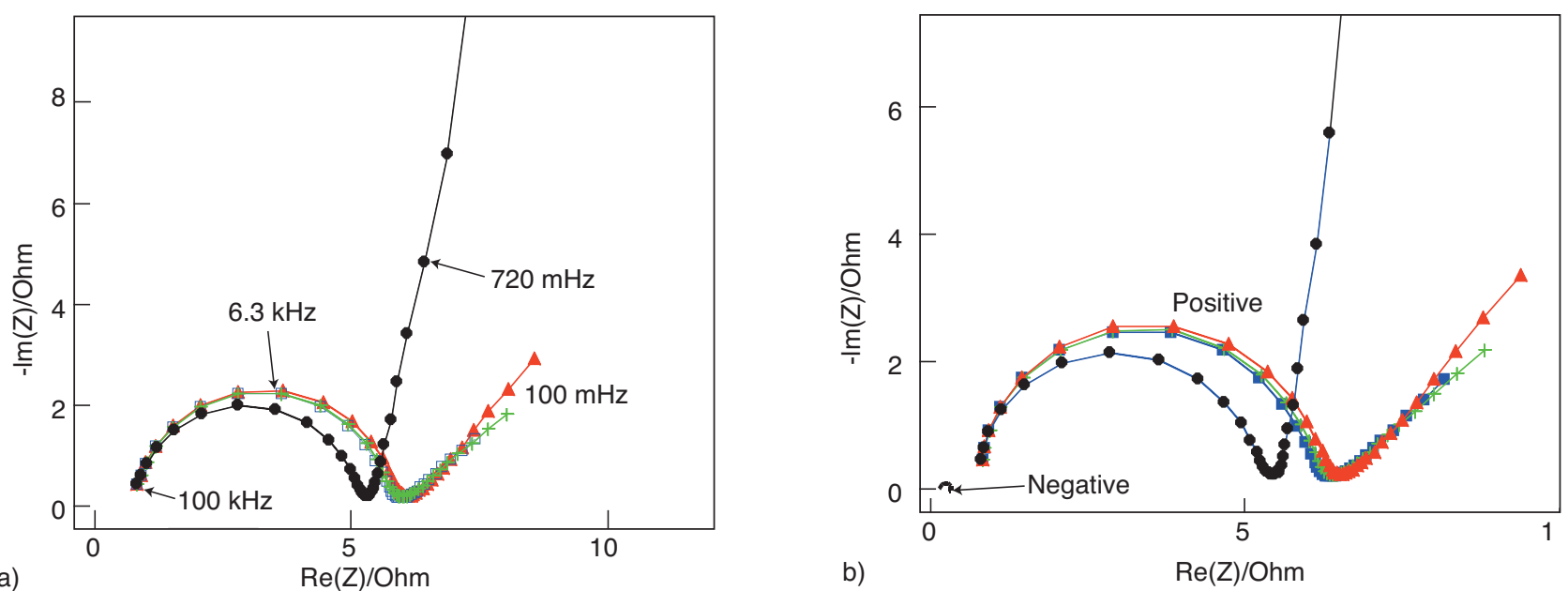

Figure 11

EIS diagrams for a Pouch cell $\mathrm{LiFePO}_{4} / \mathrm{Li}_{4} \mathrm{Ti}_{5} \mathrm{O}_{12}$ obtained during initial characterization at $20^{\circ} \mathrm{C}$. a) Entire cell; b) positive and negative electrodes. SoC $100 \%$ (black circles), $80 \%$ (blue squares), $40 \%$ (green crosses), and 0\% (red triangles).

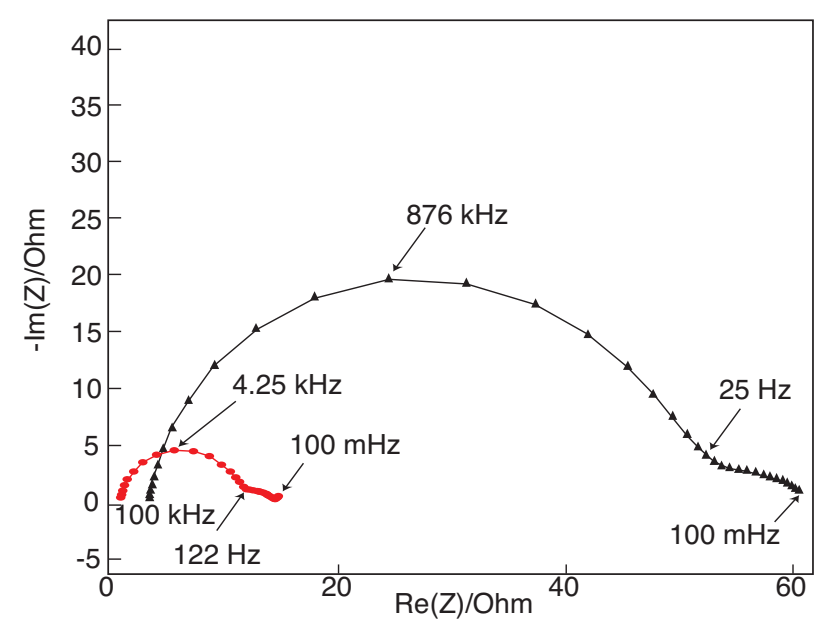

Figure 12

2-electrode EIS diagrams for a Pouch cell $\mathrm{LiNiCoAlO}_{2} /$ graphite at $\mathrm{SoC} 60 \%$ obtained during characterization at $20^{\circ} \mathrm{C}$ before ageing (red circles) and after 1-month ageing (black triangles).

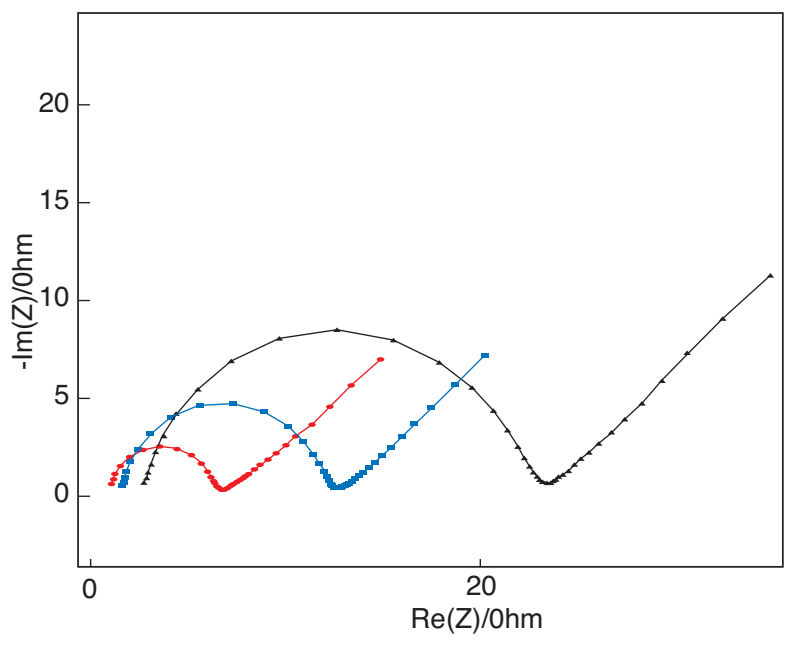

Figure 13

EIS diagrams for a $\mathrm{LiFePO} / \mathrm{Li}_{4} \mathrm{Ti}_{5} \mathrm{O}_{12}$ cell at $\mathrm{SoC} 60 \%$ for the entire cell at initial state (red circles), after 1-month ageing (blue squares) and after 2-month ageing (black triangles). significant evolution of the diagram can be observed. Only the full SoC shows an evolution of the low-frequency line that becomes vertical. It can then be concluded that it may be impossible to extract a parameter representative of the SoC with $\mathrm{LiFePO}_{4} / \mathrm{Li}_{4} \mathrm{Ti}_{5} \mathrm{O}_{12}$ chemistry in the initial state.

\subsection{Ageing of Li-ion Cells}

After ageing at $50^{\circ} \mathrm{C}$ in a thermal chamber, the cells were cooled down to $20^{\circ} \mathrm{C}$ and submitted to the check-up protocol. The 2-electrode EIS diagram measured at a SoC of $60 \%$ in potentiostatic mode after a $30 \mathrm{~min}$ rest time period is given in Figure 12 for a $\mathrm{LiNiCoAlO}_{2} /$ graphite cell after one month of ageing and in Figure 13 for a $\mathrm{LiFePO}_{4} / \mathrm{Li}_{4} \mathrm{Ti}_{5} \mathrm{O}_{12}$ cell after one and two months of ageing. Initial diagrams are also presented for comparison purpose. 3-electrode EIS results monitored continuously during ageing and recorded after ageing during the check-up will be presented and discussed for both technologies as soon as available.

One can observe that in both cases the electrolyte resistances $R_{\mathrm{HF}}$ at high frequency is markedly increased, suggesting the occurrence of degradation phenomena. Further investigation will be conducted to distinguish between thermal effects and electrolyte interaction with 
electrode materials. Furthermore, the impedance of the LiNiCoAlO 2 /graphite cell, still composed of two partially overlapping semi-circles, is significantly increased after ageing, in agreement with results reported in the literature $[8,20,21]$. During ageing, the $\mathrm{LiFePO}_{4} / \mathrm{Li}_{4} \mathrm{Ti}_{5} \mathrm{O}_{12}$ cell still shows a classical EIS diagram with a single semi-circle in the medium frequency range and a straight line at low frequency that can be attributed to diffusion processes. The size of the semi-circle increased between ageing phases suggesting also degradation phenomena. The 3 -electrode EIS data will help to explain this enhancement of the charge-transfer resistance. Post-mortem diagnosis is also in progress to investigate the ageing issue.

Additional calendar-life ageing tests will also be performed at $50^{\circ} \mathrm{C}$ to identify the impact of the temperature alone on ageing but also to compare the relevance of our accelerating-ageing tests.

\section{CONCLUSIONS AND PERSPECTIVES}

The ALIDISSI project is aimed at evaluating EIS as a diagnosis tool for Li-ion batteries to be used in future hybrid electric vehicles and on-grid photovoltaic systems. This study started in early 2008 with the preparation of the pouch $\mathrm{Li}$-ion cells and the preliminary 3-electrode EIS measurements of Liion cells as a function of current, temperature, and during representative ageing cycles. EIS diagrams obtained on an emerging electrode couple $\left(\mathrm{LiFePO}_{4} / \mathrm{Li}_{4} \mathrm{Ti}_{5} \mathrm{O}_{12}\right)$ and a conventional one ( $\mathrm{LiNiCoAlO}_{2}$ /graphite) reveal self-consistency and reproducibility of the experimental set-up. A better comprehension of the electrochemical phenomena occurring at both electrodes and their respective footprint in EIS is expected in the near future. Ageing mechanisms of the $\mathrm{LiFePO}_{4} / \mathrm{Li}_{4} \mathrm{Ti}_{5} \mathrm{O}_{12} \mathrm{Li}$-ion systems, in particular, need to be clarified.

On the basis of impedance parameters representative of $\mathrm{SoC}$ and $\mathrm{SoH}$, a new tool for non-intrusive and in-situ diagnosis of batteries will be developed and validated with a 2electrode set-up on commercial Li-ion systems, enlarging the application scope of the work.

\section{ACKNOWLEDGMENTS}

Support from the Stock-E Program of the French ANR is gratefully acknowledged. Authors also wish to acknowledge the AXELERA pole for the labelling of the project.

\section{REFERENCES}

1 Huet F. (1998) A review of impedance measurements for determination of the state-of-charge or state-of-health of secondary batteries, J. Power Sources 70, 1, 59-69.
2 Hammouche A., Karden E., De Doncker R.W. (2004) Monitoring state-of-charge of Ni-MH and Ni-Cd batteries using impedance spectroscopy, J. Power Sources 127, 1-2, 105-111.

3 Nagasubramanian G. (2000) Two- and three-electrode impedance studies on $18650 \mathrm{Li}$-ion cells, J. Power Sources 87, 1-2, 226-229.

4 Dolle M., Orsini F., Gozdz A.S., Tarascon J.M. (2001) Development of reliable three-electrode impedance measurements in plastic Li-ion batteries, J. Electrochem. Soc. 148, 8, A851-A857.

5 Abraham D.P., Liu J., Chen C.H., Hyung Y.E., Stoll M., Elsen N., MacLaren S., Twesten R., Haasch R., Sammann E., Petrov I., Amine K., Henriksen G. (2003) Diagnosis of power fade mechanisms in high-power lithium-ion cells, J. Power Sources 119-121, 511-516.

6 Abraham D.P., Poppen S.D., Jansen A.N., Liu J., Dees D.W. (2004) Application of a lithium-tin reference electrode to determine electrode contributions to impedance rise in highpower lithium-ion cells, Electrochim. Acta 49, 26, 47634775 .

7 Song J.Y., Lee H.H., Wang Y.Y., Wan C.C. (2002) Two- and three-electrode impedance spectroscopy of lithium-ion batteries, J. Power Sources 111, 2, 255-267.

8 Vetter J., Novak P., Wagner M.R., Veit C., Moller K.C., Besenhard J.O., Winter M., Wohlfahrt-Mehrens M., Vogler C., Hammouche A. (2005) Ageing mechanisms in lithiumion batteries, J. Power Sources 147, 1-2, 269-281.

9 Broussely M., Biensan P., Bonhomme F., Blanchard P., Herreyre S., Nechev K., Staniewicz R.J. (2005) Main aging mechanisms in Li ion batteries, J. Power Sources 146, 1-2, 90-96.

10 Zaghib K., Simoneau M., Armand M., Gauthier M. (1999) Electrochemical study of $\mathrm{Li}_{4} \mathrm{Ti}_{5} \mathrm{O}_{12}$ as negative electrode for Li-ion polymer rechargeable batteries, J. Power Sources 8182, 300-305.

11 Zaghib K., Ravet N., Gauthier M., Gendron F., Mauger A., Goodenough J.B., Julien C.M. (2006) Optimized electrochemical performance of $\mathrm{LiFePO}_{4}$ at $60^{\circ} \mathrm{C}$ with purity controlled by SQUID magnetometry, J. Power Sources 163, 1, 560-566.

12 Zaghib K., Dontigny M., Charest P., Labrecque J.F., Guerfi A., Kopec M., Mauger A., Gendron F., Julien C.M. (2008) Aging of $\mathrm{LiFePO}_{4}$ upon exposure to $\mathrm{H}_{2} \mathrm{O}, J$. Power Sources 185, 2, 698-710.

13 Takei K., Kumai K., Kobayashi Y., Miyashiro H., Terada N., Iwahori T., Tanaka T. (2001) Cycle life estimation of lithium secondary battery by extrapolation method and accelerated aging test, J. Power Sources 97-98, 697-701.

14 FreedomCar, FreedomCar Battery Test Manual For Powerassist hybrid Electric vehicle, 2003, INEEL/DOE.

15 Badin F., Jeanneret B., Trigui R., Harel F., Jullien A., Hannebique M., Van Berten M., Metkejmeijer R., Mayer D., Smaha M., Verdier L., Beretta J., Porcellato M., Parmentier M., Durand M., D’Ussel L., Bariand M., Biscaglia S. (2000) Electric Vehicle Association of the Americas: EVS 17 - 17th International Electric Vehicle Symposium, Montréal, Québec, Canada, October 16-18, 2000.

16 Liberal, Test Procedures Final Draft Issue - WP4: Operational Profiles \& accelerated battery life test procedures, 2007.

17 P. Alto, Assessment of Advance Batteries for Energy Storage Applications in Deregulated Electric Utilities, EPRI, CA, 1998, TR111162. 
18 P. Alto, EPRI-DOE Handbook supplement of Energy Storage for Grid Connected Wind Generation Applications, EPRI, CA and the U.S. Department of Energy, Washington, DC, 2004, 1008703 .

19 Aurbach D., Markovsky B., Talyossef Y., Salitra G., Kim H.J., Choi S. (2006) Studies of cycling behavior, ageing, and interfacial reactions of $\mathrm{LiNi}_{0.5} \mathrm{Mn}_{1.5} \mathrm{O}_{4}$ and carbon electrodes for lithium-ion 5-V cells, J. Power Sources $\mathbf{1 6 2}$, 2, 780-789.
20 Chen C.H., Liu J., Amine K. (2001) Symmetric cell approach and impedance spectroscopy of high power lithium-ion batteries, J. Power Sources 96, 2, 321-328.

21 Dolle M., Orsini F., Gozdz A.S., Tarascon J.M. (2001) Development of reliable three-electrode impedance measurements in plastic Li-ion batteries, J. Electrochem. Soc. 148, 8, A851-A857.

Final manuscript received in August 2009 Published online in November 2009 or distributed for profit or commercial advantage and that copies bear this notice and the full citation on the first page. Copyrights for components of this work owned by others than IFP must be honored. Abstracting with credit is permitted. To copy otherwise, to republish, to post on servers, or to redistribute to lists, requires prior specific permission and/or a fee: Request permission from Documentation, Institut français du pétrole, fax. +33147527078 , or revueogst@ifp.fr. 